\title{
Recovery of suppressed male reproduction in mice exposed to progesterone during embryonic development by testosterone
}

\author{
C Harini ${ }^{1}$, S B Sainath ${ }^{1}$ and P Sreenivasula Reddy ${ }^{1,2}$ \\ Departments of ${ }^{1}$ Biotechnology and ${ }^{2}$ Zoology, Sri Venkateswara University, Tirupati 517 502, India \\ Correspondence should be addressed to P S Reddy; Email: reddy_1955@yahoo.co.in
}

\begin{abstract}
The present study aimed to examine whether transplacental exposure to progesterone caused male reproductive abnormalities and whether the changes can be reversed after testosterone administration. Progesterone was injected to mice on day 1, 3, and 7 of pregnancy. The male pups (F1 generation) were allowed to grow for 50 days and assessed for reproductive performance. Gestational exposure to progesterone $(7 \mathrm{mg} / \mathrm{kg}$ body weight) resulted in significant body weight gain with a decrease in reproductive tissue indices in mice. Total sperm count, viable sperm, and motile sperm decreased in experimental mice. Hypo-osmotic swelling test revealed that experimental mice sperm membrane integrity was severely altered. The activity levels of testicular steroidogenic marker enzymes (hydroxy-delta-5-steroid dehydrogenase, 3 beta- and steroid delta-isomerase cluster (HSD3B) and hydroxysteroid (17-beta) dehydrogenase 1 (HSD17B)) decreased significantly in mice exposed to progesterone during embryonic development when compared with the controls. The levels of serum testosterone decreased with an increase in serum FSH and $\mathrm{LH}$ in mice exposed to progesterone during embryonic development. Prenatal exposure to progesterone caused significant reduction in the number of spermatozoa and increase in the lumen of seminiferous tubule. The experimental mice that cohabited with normal females showed fertility reduction. Administration of testosterone $(4.16 \mathrm{mg} / \mathrm{kg} \mathrm{body}$ weight) on postnatal day 20, 30, and 40 to progesterone-exposed prenates resulted in recovery of progesterone-induced suppressed male reproduction. It is suggested that the impairment of male reproduction in mice exposed to progesterone during embryonic development could be mediated through the inhibition of testosterone production. These results also indicate that in utero exposure to progesterone affects male reproduction and that supplementation of testosterone restores the suppressed male reproduction.
\end{abstract}

Reproduction (2009) 137 439-448

\section{Introduction}

Progesterone is widely prescribed in southern parts of India to prevent abnormal uterine bleeding and threatened miscarriage. Similarly, testosterone is prescribed to treat patients with hypogonadal disorder and testicular dysfunction. Administration of testosterone is known to restore secondary sexual characteristics and erectile dysfunction (Weinbauer \& Nieschlag 1990, Robbins 1996, Bhasin \& Bremner 1997, Barrett-Connor \& Bhasin 2004). Studies indicate a progressive increase in disorders of male and female reproduction and there is concern as to whether man-made compounds could have contributed to these changes. During the past 50 years fertility has become an increasingly important issue. Studies indicate a decrease in sperm count (Nelson \& Bunge 1974, Carlsen et al. 1992) and an increase in testicular cancer and reproductive tract malformations during the past 50 years (McLachlan et al. 1975, Gill et al. 1979, Forman \& Moller 1994, Jensen et al. 1995, Toppari et al. 1996, Paulozzi 1999). Exposure to estrogenic chemicals or excess female hormones in utero may adversely affect male reproductive tract and sperm quality. This is also supported by studies on wildlife populations exposed to estrogenic chemicals in the environment (Carlsen et al. 1992, Korach et al. 1996, Hess et al. 1997, Vos et al. 2000, Luconi et al. 2002). Many wildlife species have suffered a decline in male reproductive health and this decrease has been extensively studied (Sharpe \& Skakkebaek 1993, Toppari et al. 1996). The children of diethylstilbestrol (DES) exposed women are suffering with increased reproductive abnormalities (Takasugi \& Bern 1988, Hines 1992).

There are reports indicating that when estrogenic chemicals are administered to animals during fetal and/or neonatal life, abnormalities can result in neural, mammary gland, and reproductive tract of males and females (McGinley et al. 1992, Aitken et al. 2006, Anway \& Skinner 2006). Sharpe \& Skakkebaek (1993) also proposed that the increasing incidence of human testicular cancer may be due to exposure to estrogenic chemicals during embryonic development. It has been hypothesized that exposure to supranormal levels of estrogen-like chemicals during embryonic development may interfere with mechanisms involved in the development of the male reproductive system and in determining 
Table 1 Injection of testosterone depot on tissue somatic index of adult mice exposed to progesterone during embryonic development.

\begin{tabular}{lccc}
\hline Tissue & Normal & Progesterone-exposed $(\mathrm{P})$ & Testosterone-supplemented $(\mathrm{P}+\mathrm{T})$ \\
\hline Liver & $4.94^{\mathrm{a}} \pm 0.69$ & $4.78^{\mathrm{a}} \pm 0.57(-3.24)$ & $4.85^{\mathrm{a}} \pm 0.74(-1.82)$ \\
Brain & $1.18^{\mathrm{a}} \pm 0.15$ & $1.19^{\mathrm{a}} \pm 0.16(-0.85)$ & $1.09^{\mathrm{a}} \pm 0.14(-7.62)$ \\
Kidney & $1.84^{\mathrm{a}} \pm 0.22$ & $1.69^{\mathrm{a}} \pm 0.24(-8.15)$ & $1.75^{\mathrm{a}} \pm 0.18(-4.89)$ \\
Testes & $0.75^{\mathrm{a}} \pm 0.014$ & $0.52^{\mathrm{b}} \pm 0.014(-44.2)$ & $0.74^{\mathrm{a}} \pm 0.09(42.30)$ \\
Epididymides & $1.15^{\mathrm{a}} \pm 0.33$ & $0.78^{\mathrm{b}} \pm 0.22(-32.17)$ & $1.20^{\mathrm{a}} \pm 0.124(53.85)$ \\
Seminal vesicle & $0.93^{\mathrm{a}} \pm 0.049$ & $0.61^{\mathrm{b}} \pm 0.28(-34.41)$ & $0.91^{\mathrm{a}} \pm 0.026(49.18)$ \\
Prostate gland & $0.18^{\mathrm{a}} \pm 0.028$ & $0.062^{\mathrm{b}} \pm 0.028(-65.55)$ & $0.113^{\mathrm{a}} \pm 0.032(82.26)$ \\
\hline
\end{tabular}

Values expressed as $\mathrm{g} \%$ are mean \pm s.D. of eight animals. Values in parentheses are $\%$ change from control. For calculation of $\%$ change for ' $\mathrm{P}$ ' group, normal served as control; for ' $\mathrm{P}+\mathrm{T}^{\prime}$ ' group, ' $\mathrm{P}$ ' group served as control. Values with same superscript do not differ significantly from each other.

sperm numbers (Sharpe \& Skakkebaek 1993, Adami et al. 1994). Hence, it is clear from the above reports that estrogens play an important role in male reproduction, but their mechanisms of action in reproductive physiology or in inducing reproductive abnormalities remain unclear. Considering the potential implications of the above results for human health, the present study aimed to determine the effects of prenatal exposure to progesterone on male reproductive parameters at adulthood in Swiss albino mice.

The purpose of the present set of experiments was twofold. First, we determined which end points of reproduction were affected in male mice exposed to progesterone during embryonic development. This study was conducted in an effort to replicate our earlier studies that administered hydroxyprogesterone to pregnant rats and determined the F1 generation male reproductive potential. In utero exposure to hydroxyprogesterone caproate caused a significant decrease in the activity levels of steroidogenic enzymes, decreased sperm count, sperm motility, and decreased reproductive potential in first generation males (Pushpalatha et al. 2003, 2004, 2005). Secondly, we established whether the suppressed reproductive potential of male mice exposed to progesterone during embryonic development can be restored by testosterone. Therefore, these data suggest that the suppressed reproduction in F1 generation male mice is mainly due to decreased production of testosterone.

\section{Results}

No mortality and no behavioral abnormalities were recorded in mice exposed to progesterone during embryonic development, indicating that progesterone does not show any signs of toxicity but showed signs of suppressed reproduction at the selected dose level. None of the control or treated mice was excluded from the experiment.

\section{Body and reproductive organ weights}

The mean final body weights ( \pm s.D.) at 70 days of age in male mice exposed to progesterone during embryonic development and with or without testosterone substitution were $28.75 \pm 2.16$ and $29.81 \pm 2.73$ g respectively, and neither weight was significantly different from that of controls $(29.16 \pm 2.36 \mathrm{~g})$. However, the weight of testes $(P<0.001)$, epididymis $(P<0.05)$, seminal vesicle $(P<0.05)$, and ventral prostate $(P<0.05)$ were altered by $44.2,32.17,34.41$, and $65.55 \%$ respectively in mice exposed to progesterone. The weights of these organs increased to control levels in mice also administered testosterone (Table 1). However, no difference in weights of liver, brain, and kidney from control was observed in mice transplacentally exposed to progesterone and with or without testosterone treatment during post-natal development (Table 1).

\section{Sperm quality and quantity}

The mean sperm numbers in cauda epididymis were $52.6 \pm 9.61$ in the control group, but decreased to almost $51.53 \%$ of the control value in mice treated with progesterone prenatal, and increased to the control level in mice substituted with testosterone (Table 2). The number of motile sperm was significantly decreased $(10.53 \%)$ and the percentage of viable sperm also showed a $33.11 \%$ decrease in comparison to control.

Table 2 Injection of testosterone depot on epididymal sperm count, sperm motility, sperm viability, and hypo-osmotic swelling (HOS) tail coiled sperm in mice exposed to progesterone during embryonic development.

\begin{tabular}{llcc}
\hline Parameter & \multicolumn{1}{c}{ Normal } & Progesterone-exposed $(\mathrm{P})$ & Testosterone-supplemented $(\mathrm{P}+\mathrm{T})$ \\
\hline Sperm count (millions/ml) & $52.61^{\mathrm{a}} \pm 9.61$ & $25.49^{\mathrm{b}} \pm 3.20(-51.53)$ & $34.65^{\mathrm{c}} \pm 3.040(35.93)$ \\
Motile sperm (\%) & $60.65^{\mathrm{a}} \pm 10.39$ & $54.26^{\mathrm{a}} \pm 3.35(-10.53)$ & $60.06^{\mathrm{a}} \pm 1.125(10.68)$ \\
Viable sperm (\%) & $67.71^{\mathrm{a}} \pm 684$ & $45.28^{\mathrm{b}} \pm 5.11(-33.11)$ & $57.5^{\mathrm{c}} \pm 2.51(26.98)$ \\
HOS tail coiled sperm (\%) & $60.12^{\mathrm{a}} \pm 2.82$ & $43.68^{\mathrm{b}} \pm 8.62(-27.2)$ & $55.6^{\mathrm{a}} \pm 5.419(27.28)$
\end{tabular}

Values are mean \pm S.D. of eight animals. Values in parentheses are $\%$ change from control. For calculation of $\%$ change for ' $P$ ' group, normal served as control; for ' $\mathrm{P}+\mathrm{T}^{\prime}$ group, ' $\mathrm{P}$ ' group served as control. Values with same superscript do not differ significantly from each other. 
Table 3 Injection of testosterone depot on hydroxy-delta-5-steroid dehydrogenase, 3 beta- and steroid delta-isomerase cluster (HSD3B) and hydroxysteroid (17-beta) dehydrogenase 1 (HSD17B) activity levels in the testis of mice exposed to progesterone during embryonic development.

\begin{tabular}{lccc}
\hline Enzyme & Normal & Progesterone-exposed $(\mathrm{P})$ & Testosterone-supplemented $(\mathrm{P}+\mathrm{T})$ \\
\hline HSD3B ( $\mu \mathrm{mol}$ of NAD converted to & $0.0246^{\mathrm{a}} \pm 0.0043$ & $0.0124^{\mathrm{b}} \pm 0.0029(-49.59)$ & $0.0208^{\mathrm{a}} \pm 0.0027(67.74)$ \\
$\quad$ NADH/mg protein/min) & $0.0153^{\mathrm{a}} \pm 0.0012$ & $0.0047^{\mathrm{b}} \pm 0.0016(-69.28)$ & $0.0131^{\mathrm{a}} \pm 0.0021(178.72)$ \\
$\begin{array}{l}\text { HSD17B }(\mu \mathrm{mol} \text { of NADPH converted to } \\
\text { NADP/mg protein/min) }\end{array}$ & & &
\end{tabular}

Values are mean \pm s.D. of eight animals. Values in parentheses are $\%$ change from control. For calculation of $\%$ change for ' $\mathrm{P}$ ' group, normal served as control; for ' $\mathrm{P}+\mathrm{T}^{\prime}$ group ' $\mathrm{P}$ ' group served as control. Values with same superscript do not differ significantly from each other.

Also, a significant decrease in sperm hypo-osmotic swelling (HOS) coiling was observed in mice exposed to progesterone in utero (Table 2). Administration of testosterone to in utero progesterone-exposed mice showed recovery of these parameters to control levels (Table 2).

\section{Testicular steroidogenic marker enzyme activity levels}

Gestational exposure to progesterone resulted in a significant decrease in HSD3B and HSD17B1 activity levels in the testes of mice when compared with controls. These enzyme activities increased to the control level in the testis of mice substituted with testosterone (Table 3).

\section{Serum reproductive hormone levels}

Exposure to progesterone during embryonic stages resulted in $22.6 \%$ decrease in serum testosterone levels when compared with control (Table 4). However, serum FSH and LH levels were elevated significantly $(P<0.01$ and $P<0.05)$ by 126.6 and $71.6 \%$ respectively in progesterone-exposed mice (Table 4). Administration of testosterone to mice exposed to progesterone during embryonic development resulted in an increased level of testosterone and decreased levels of FSH and $\mathrm{LH}$ to control levels (Table 4).

\section{Testis histological observations}

In the normal testes, seminiferous tubules are compactly arranged with well-developed germinal epithelium as well as sperm cells in each tubule (Fig. 1A). The seminiferous tubule showed successive stages of transformation of spermatogonia into spermatozoa.
Marked degenerative changes were observed in testes of mice exposed to progesterone. These changes include damaged seminiferous tubules that showed decreased spermatogenic activity; the lumen was large and devoid of sperm (Fig. 1B). Partial recovery of testicular architecture was observed in mice substituted with testosterone (Fig. 1C).

\section{Fertility examinations}

Fertility-related parameters studied were mating index, fertility index, the number of corpora lutea per dam, the number of implantations per dam and pre- and postimplantation losses. The fertility index of experimental male mice was evaluated based on their ability to impregnate control female mice. All the females $(n=24)$ mated with males in the control mice, had copulatory plugs and delivered 11-13 pups each (fertility index $=100 \%$ and mating index $=100 \%$; Table 5). Of the 30 females that cohabited with in utero progesterone-exposed males, only 20 had copulatory plugs (copulatory index $=66.67 \%$ ) and of these 16 mice delivered three to five pups each (fertility index $=$ $53.33 \%$ ). The copulatory index and mating index was $79.99 \%$ in females mated with testosterone treated mice. The mean number of corpora lutea in females mated with different groups of males was comparable among the three groups (control, $12.63 \pm 0.53$, progesteroneexposed, $13.03 \pm 1.12$, and testosterone substituted, $12.45 \pm 0.92$ ). The mean number of implantations in females mated with progesterone-exposed males decreased $(39.39 \%)$ significantly, in contrast to $12.44 \pm 0.42$ and $11.71 \pm 1.02$ for the control and testosterone-supplemented mice respectively. The pre-implantation loss was $42.13 \%$ for progesterone-exposed group, in contrast to 5.94 and $1.50 \%$ for the testosterone-supplemented and

Table 4 Injection of testosterone depot on levels of serum testosterone, FSH, and $\mathrm{LH}$ in mice exposed to progesterone during embryonic development.

\begin{tabular}{lccc}
\hline Hormone & Normal & Progesterone-exposed $(\mathrm{P})$ & Testosterone-supplemented $(\mathrm{P}+\mathrm{T})$ \\
\hline Testosterone $(\mathrm{ng} / \mathrm{ml})$ & $7.32^{\mathrm{a}} \pm 0.81$ & $5.66^{\mathrm{b}} \pm 0.62(22.6)$ & $6.78^{\mathrm{a}} \pm 0.82(19.78)$ \\
FSH $(\mathrm{ng} / \mathrm{ml})$ & $4.31^{\mathrm{a}} \pm 0.71$ & $9.77^{\mathrm{b}} \pm 1.43(126.6)$ & $6.94^{\mathrm{c}} \pm 0.57(28.96)$ \\
LH $(\mathrm{ng} / \mathrm{ml})$ & $1.62^{\mathrm{a}} \pm 0.22$ & $2.78^{\mathrm{b}} \pm 0.41(71.06)$ & $1.94^{\mathrm{a}} \pm 0.24(-30.21)$
\end{tabular}

Values are mean \pm s.D. of eight animals. Values in parentheses are $\%$ change from control. For calculation of $\%$ change for ' $P$ ' group, normal served as control; for ' $\mathrm{P}+\mathrm{T}^{\prime}$ group, ' $\mathrm{P}$ ' group served as control. Values with same superscript do not differ significantly from each other. 


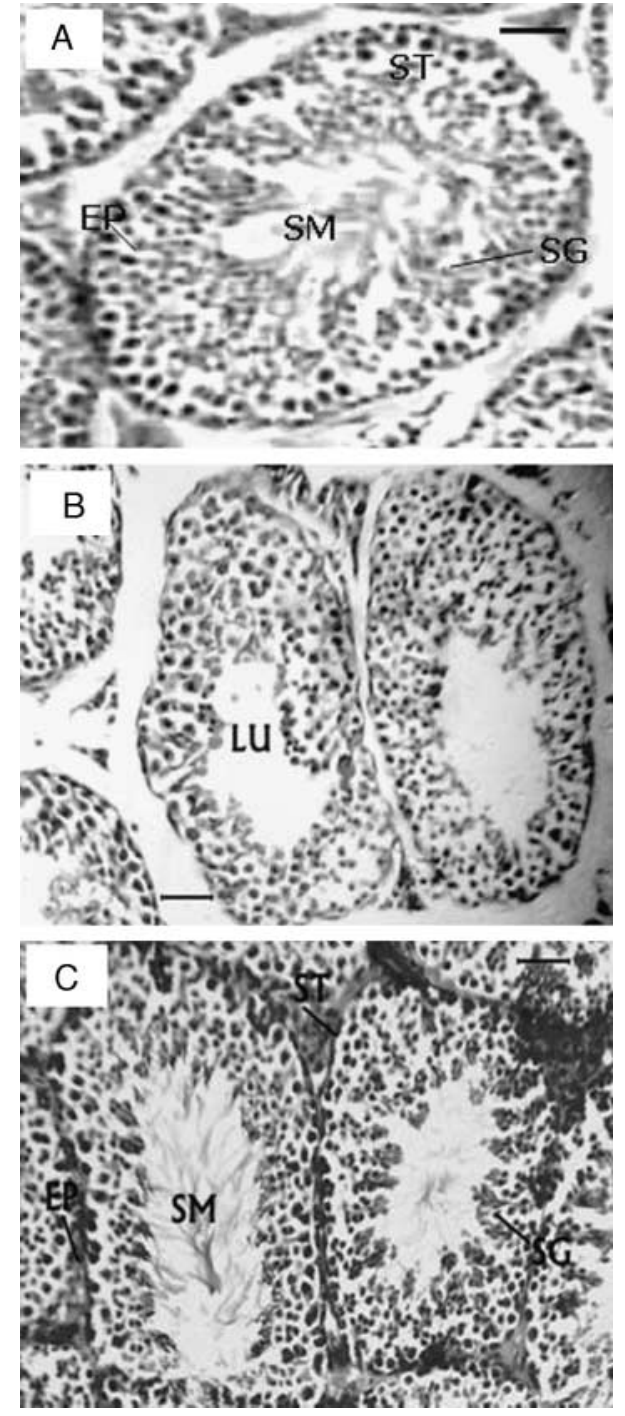

Figure 1 (A) Microphotograph of control mouse testis showing circumscribed seminiferous tubules with intact basement membrane. All successive stages of spermatogenesis are seen; the lumen is filled with spermatozoa. EP, epithelium; ST, seminiferous tubule; SG, spermatogonia; SM, sperm. Scale bar $=50 \mu \mathrm{m}$. (B) Microphotograph of testis from mouse exposed to progesterone in utero $(7.5 \mathrm{mg} / \mathrm{kg} \mathrm{bw})$ showing a large lumen devoid of sperm. Scale bar $=50 \mu \mathrm{m}$. (C) Microphotograph of testis from testosterone-injected mouse exposed to progesterone in utero $(7.5 \mathrm{mg} / \mathrm{kg}$ bw) showing recovery of testicular architecture. LU, lumen; SM, sperm. Scale bar $=50 \mu \mathrm{m}$.

control groups respectively. The post-implantation loss for the control, progesterone-exposed, and testosteronesupplemented groups was $0.80,35.94$, and $16.05 \%$ respectively.

\section{Discussion}

Recently, there has been increased awareness of the possible effects of prenatal and/or neonatal exposure to supranormal levels of female sex hormones or estrogen mimics on male reproduction (Vandenbergh 2004).
Progesterone is one of the commonly prescribed drugs to control excess uterine bleeding and to protect threatened abortions in southern parts of India and is available under different trade names. In the present study, progesterone was administered to mice on day 1,3 , and 7 of pregnancy at a dose level of $7.5 \mathrm{mg} / \mathrm{kg}$ body weight, which brought about marked alterations on the following reproductive endpoints: 1 ) weight of reproductive organs, 2) sperm quantity and quality, 3) reproductive hormones, 4) histology of testis, and 5) fertility. The dose of progesterone used in this study was in the range of regular clinical use and the administrative schedule is similar to humans during pregnancy. Pregnant women were prescribed with progesterone at a dose of $5-10 \mathrm{mg} / \mathrm{kg}$ body weight per injection. Intramuscular injections were given weekly up to 12 weeks of pregnancy (Monthly Index of Medical Specialties, ISSN: 0970-1036, Vol. 26, pp 155). Results of the study provided clear evidence that prenatal exposure to progesterone resulted in reduction in testosterone production thereby suppressed male reproduction. In addition, they confirmed earlier reports that indicated significant changes in weights of the reproductive organs, quality and quantity of sperm, serum reproductive hormone concentrations, and fertility at maturity following prenatal and/or neonatal exposure to estrogenic compounds in rats (Brown-Grant et al. 1975, Arai et al. 1983, Bellido et al. 1990, Lee 1998, Sharpe et al. 1998, Goyal et al. 2003, 2004), mice (McLachlan et al. 1975, Jones 1980, Thayer et al. 2001), hamsters (Khan et al. 1998), and rabbits (Orgebin-Crist et al. 1983).

An important finding of the present study was the significant reduction in weights of all reproductive organs, including the testis, epididymis, seminal vesicle, and prostate gland in progesterone-exposed mice. The reduction in testicular weight may be due to degeneration of germinal epithelium (Takihara et al. 1987). The observed loss in weight of epididymis, and the seminal vesicle may be due to decrease in sperm count. The decrease in the weight of testis and accessory sex organs have been reported in rats following neonatal exposure to estradiol benzoate (Putz et al. 2001) and DES (Goyal et al. 2003). It is also well known that the levels of androgens regulate the growth of accessory organs. Reduction in weight of accessory sex organs in the progesterone-exposed mice directly supports the reduced availability of androgens (Mann 1974). In the present study, the levels of serum testosterone are reduced in adult animals following prenatal exposure to progesterone. However, there was no change in body weight, liver, brain, and kidney weight of in utero progesterone-exposed animals, indicating that the general condition of the animals was normal.

A significant decrease in sperm volume and progressive forward motility and percentage of viable sperm and HOS coiled sperm indicated that exposure to 
Table 5 Injection of testosterone on reproductive performance of mice exposed to progesterone during embryonic development.

\begin{tabular}{|c|c|c|c|}
\hline Parameter & Normal & Progesterone-exposed $(\mathrm{P})$ & Testosterone-supplemented $(\mathrm{P}+\mathrm{T})$ \\
\hline Number of litters & 24 & 30 & 30 \\
\hline Number of copulation trials ${ }^{a}$ & $1.18 \pm 0.42$ & $3.11 * \pm 0.68(163.56)$ & $1.56^{\dagger} \pm 0.65(32.73)$ \\
\hline Mating index ${ }^{\mathrm{b}}$ & $100 \%(24 / 24)$ & $66.67 \%(20 / 30)$ & $79.99 \%(24 / 30)$ \\
\hline Fertility index ${ }^{c}$ & $100 \%(24 / 24)$ & $53.33 \%(16 / 30)$ & $79.99 \%(24 / 30)$ \\
\hline Number of corpora lutea per mouse $\mathrm{e}^{\mathrm{a}}$ & $12.63 \pm 0.53$ & $13.03 \pm 1.12(5.78)$ & $12.45 \pm 0.92(1.43)$ \\
\hline Number of implantations/mouse $\mathrm{a}^{\mathrm{a}}$ & $12.44 \pm 0.42$ & $7.54^{*} \pm 0.58(39.39)$ & $11.71 \pm 1.02(5.89)$ \\
\hline Percentage of pre-implantation loss ${ }^{\mathrm{d}}$ & 1.50 & $42.13^{-0.00103 .19}$ & 5.94 \\
\hline Live fetuses/mouse ${ }^{\mathrm{a}}$ & $12.31 \pm 0.86$ & $4.83^{*} \pm 0.91(60.76)$ & $9.83^{\dagger} \pm 0.84(20.15)$ \\
\hline Percentage of post-implantation loss $\mathrm{e}$ & 0.80 & 35.94 & 16.05 \\
\hline Body weight of live pups $(\mathrm{g})^{\mathrm{a}}$ & $4.11 \pm 0.18$ & $2.84^{*} \pm 0.28(30.90)$ & $4.02 \pm 0.21(2.19)$ \\
\hline
\end{tabular}

Values in parentheses are $\%$ change from control. For calculation of $\%$ change for ' $\mathrm{P}$ ' group, normal served as control; for ' $\mathrm{P}+\mathrm{T}^{\prime}$ group, ' $\mathrm{P}$ ' group served as control. Values are significantly different from control at $* P<0.001 ;{ }^{\dagger} P<0.05$.

${ }^{\mathrm{a}}$ Values are given as mean \pm s.D. ${ }^{\mathrm{b}}$ Number of sperm positive females/no. of pairings. ${ }^{\mathrm{c}}$ Number of pregnancies/no. of pairings. ${ }^{\mathrm{d}}((\mathrm{Number}$ of corpora lutea - no. of implantations $) /$ no. of corpora lutea $) \times 100$. ${ }^{\mathrm{e}}(($ Number of implantations - no. of live fetuses $) /$ no. of implantations $) \times 100$.

progesterone during early stages of development severely affected not only the production of sperm but also affected their quality. Although few studies have examined effects of estradiol on sperm quality, the percentage of motile sperm was significantly reduced in rats treated with ethinyl estradiol after 1 week of treatment at $10 \mathrm{mg} / \mathrm{kg}$ body weight and after 2 weeks of treatment at $1 \mathrm{mg} / \mathrm{kg}$ body weight (Kaneto et al. 1999). An increased incidence of decapitated sperm was reported after estradiol administration to adult rats (Rao \& Chinoy 1983). It is also established that prenatal and/or neonatal exposure to estrogenic compounds leads to smaller testes and lower sperm production in rodents (Vornberger et al. 1994, Toppari et al. 1996, Sharpe et al. 1998). In consonance with these results, Wistar rats treated neonatally with DES showed fourfold increases in germ cell apoptosis and twofold increases in the lumen volume of seminiferous tubules than controls at adulthood (Sharpe et al. 1998). The decrease in spermatocytes and increase in lumen of the seminiferous tubules in the present study goes hand in hand with earlier results (Goyal et al. 2003).

The present results of reduced testosterone are in agreement with those of earlier studies, which also reported lower testosterone in adult animals as a consequence of female hormone treatment of neonatal and/or prenatal animals (Cooke et al. 1998, Atanassova et al. 2000). The decrease in the serum testosterone levels could be either due to the diminished responsiveness of Leydig cells to $\mathrm{LH}$ and/or the direct inhibition of testicular steroidogenesis. The activities of HSD3B and HSD17B decreased significantly in the testes of mice exposed to progesterone prenatally indicating decreased steroidogenesis. The levels of serum FSH and LH showed a significant increase in adult rats following progesterone exposure in utero. The increase in serum FSH levels could be due to the impairment of spermatogenesis in the spermatogenic compartment in the progesterone-exposed mice or through the inhibition of testosterone production. Thus, the increase in the levels serum FSH reflected the germ cell loss in the spermatogenic compartment or damage to the Sertoli cells, thereby affecting the feedback regulation of FSH secretion (van Thiel et al. 1972). The increased levels of LH together with decreased levels of serum testosterone are indicative of decreased steroidogenic ability of the testes of the mice transplacentally exposed to progesterone. Earlier reports also indicate that neonatal exposure of male rats to DES resulted in suppression of androgen action and also abnormalities of the male reproductive tract (Arai et al. 1983, Newbold \& McLachlan 1985, Marselos \& Tomatis 1992, Aceitero et al. 1998, Fisher et al. 1998, Khan et al. 1998, Sharpe et al. 1998, McKinnell et al. 2001).

The final reproductive end point studied was the effect of prenatal progesterone treatment on fertility-related parameters. All males in the control group and progesterone-exposed group sired pups. Male mice exposed to progesterone in utero were able to impregnate the unexposed females, but the rate of pregnancy was observed to be comparatively in lower number when compared with unexposed male mice. The observed decrease in male fertility of mice exposed to progesterone during embryonic development may be due to lowered epididymal sperm count, motile sperm, and viable sperm. This is well supported by the observations of Meistrich (1989) who reported that infertility occurs when the sperm count falls significantly below normal. Impaired sperm motility observed in progesterone-exposed mice may result in infertility due to the failure of sperm to reach the site of fertilization as well as their ability to penetrate the zona pellucida. Decrease in the number of HOS tail coiled sperm indicates the damage to sperm tail membrane integrity, which might also cause reduced fertility. Additional observations of fewer pups per dam and higher pre- and post-implantation losses in the progesterone-exposed mice compromised sperm fertility. Similar to our results, neonatal exposure to estrogen suppressed reproduction, as evident from the absence or reduced number of copulatory plugs with increased pre- and 
post-implantation losses (Goyal et al. 2003). Exposure of hydroxyprogesterone to mice during embryonic development resulted in a decrease in fertility index (Meistrich 1989, Pushpalatha et al. 2005). Gestational and lactational exposure of mice to DES at $10 \mu \mathrm{l} / \mathrm{kg}$ body weight/day resulted in decreased fertilizing ability in mice (Fielden et al. 2002). The observed decline in serum testosterone might be responsible for the altered sexual behavior in adult mice that were prenatally exposed to progesterone. In conclusion, this study provides compelling evidence of altered reproductive functions, including reduction in weights of reproductive organs, quantity, and quality of sperm, levels of reproductive hormones and testicular steroidogenesis, architecture of testis, fertility, and sexual behavior in adult mice that were prenatally exposed to progesterone. The increase in pre- and post-implantation losses and decreased fetal weight in mice mated with the males exposed to progesterone during embryonic development indicates paternal-mediated developmental toxicity to embryos. Whether reduced fertility observed in progesterone-exposed mice resulted from lower sperm numbers, altered sperm motility, decrease in viable sperm or depressed sexual desire cannot be determined from the present data. However, the absence of copulatory plugs in 10 out of the 30 females may indicate depressed sexual behavior in progesteroneexposed mice. Artificial insemination using a fixed number of sperm from the tail of the epididymis will be an ideal method for comparing fertility between the control and progesterone-exposed mice. Work is in progress.

The most noteworthy and novel findings of the study were the observations in mice exposed to progesterone during prenatal period supplemented with testosterone on post-natal day (PND) 20,30, and 40. Our results demonstrated the efficacy of testosterone in stimulating the suppressed male reproduction after exposure to progesterone during embryonic development in mice. The dose of testosterone used in this study was in the lower range of regular clinical use. Usual dosage schedule of testosterone enanthate for human androgen deficiency is $50-400 \mathrm{mg}$ i.m. injection every $2-4$ weeks (Wilson 1990). The dose comes to about $1-8 \mathrm{mg} / \mathrm{kg}$ body weight. In the present study, we injected testosterone enanthate to mice once in 10 days at a dose of $4.16 \mathrm{mg} /$ $\mathrm{kg}$ body weight. The administrative schedule of thrice at 10 days interval is also practical and feasible. Therefore, the dose of testosterone could be administered safely to young patients who are expected to sustain severe testicular damage due to, for example, chemotherapy for testicular cancer. In addition, exogenous testosterone could maintain the male characteristics and libido of such patients.

Although an increasing amount of evidence supports the effect of testosterone, as shown in the present study, on the recovery of impaired male reproduction, the mechanism remains elusive (Pakarainen et al. 2005, Udagawa et al. 2006). The poorly developed accessory sex organs of mice exposed to progesterone in utero developed after testosterone treatment. Testosterone initiates testicular growth and increases the number of spermatogonia and Sertoli cells (Arslan et al. 1993). Neonatal co-administration of testosterone with DES prevented severe reproductive tract development disorders in males, which occur because of androgenestrogen balance (Rivas et al. 2003). Testicular histology indicated that testosterone treatment largely, although not completely, restored the structural features of this organ. Supplementation of testosterone induced spermatogenesis. It is well established that testosterone administration promotes regeneration of impaired spermatogenesis in rats (Udagawa et al. 2006). Sperm count, the number of motile sperm, viable sperm, and HOS tail coiled sperm increased significantly after testosterone supplementation. It is well known that testosterone is essential for spermatogenesis from round spermatids (McLachlan et al. 1996, O'Donnell et al. 2001). The breeding tests indicated that testosterone-treated males were able to produce more litters per dam. To conclude, our results indicated that fertility was recovered by testosterone treatment in mice exposed to progesterone in utero.

In conclusion, we have shown in the present study that testosterone treatment restores most of the reproductive abnormalities caused by the prenatal exposure to progesterone. The treatment established complete/ partial recovery of most accessory sex organ functions, spermatogenesis, steroidogenesis, and fertility. This information will help us to develop clinical application strategies to resolve some of the male fertility problems. However, testosterone treatment did not fully repair the reproductive defects in progesterone-exposed males, which remained subfertile. The cause of reduced fertility seems to be multifactorial, and its details remain to be analyzed further.

\section{Materials and Methods}

\section{Animals and husbandry}

Albino female mice (60 days old) with a body weight $30 \pm 2 \mathrm{~g}$ were used for the present study. They were reared in an airconditioned animal house facility (temperature: $23 \pm 1{ }^{\circ} \mathrm{C}, 12 \mathrm{~h}$ light: $12 \mathrm{~h}$ darkness, relative humidity $55 \pm 5 \%$ ) at the Department of Biotechnology, Sri Venkateswara University, Tirupati, India. The mice were housed in sterilized polypropylene cages lined with paddy husk and fed on pellet diet (HLL Animal Feeds, Bangalore, India) and water ad libitum. All animal procedures were carried out in accordance with the guidelines established by the NIH Guide for the Care and Use of Laboratory Animals. This experiment was reviewed and approved by the Institutional Animal Care and Use Committee at S.V. University (438/01/a/CPSEA) and comply with the laws of the country. 


\section{Test chemical}

Progesterone purchased from Sigma was dissolved in caster oil and benzyl benzoate $(1: 1.7)$. Testosterone depot $(100 \mathrm{mg} / \mathrm{ml})$ manufactured by German Remedies, Goa, India was purchased from local drug stores.

\section{Experimental design}

After a 2-week acclimatization period, the mice were housed as breeding pairs (one male and one female). Copulation was examined every morning while evidence for mating was confirmed by the presence of a vaginal plug and/or sperm in a vaginal smear. The cohabitation period was 4 days. On the day when copulation was confirmed, pregnant mice were moved into separate cages and housed individually. The pregnant mice were randomly assigned to the control group $(n=8)$ or the progesterone group $(n=8)$. Control mice were treated the same as the experimental group but received injections of a mixture a of caster oil and benzyl benzoate $(1: 1.7)$ in $20 \mu \mathrm{l}$ volume. The mice in progesterone group were injected intraperitoneally with $7 \mathrm{mg}$ progesterone/kg body weight on first, third, and seventh-day of pregnancy. The progesterone doses selected in the present study was equivalent to the dose prescribed to humans $(4-8 \mathrm{mg} / \mathrm{kg}$ body weight: Monthly Index of Medical Specialties, ISSN: 0970-1036, Vol. 26, pp 155). Since progesterone was given to women weekly once during first trimester of pregnancy, the first, third, and seventh days of pregnancy were selected for injections. The mice were allowed to deliver the pups. The F1 generation male mice were weaned and injected intraperitoneally with either testosterone $(4.16 \mathrm{mg} / \mathrm{kg}$ body weight) or vehicle $(20 \mu \mathrm{l})$ on PND 20, 30, and 40. On PND 60, male mice from control, transplacental progesterone-exposed and progesterone exposed-testosterone injected groups were housed as breeding pairs with normal cycling females (70 days old) to be parents of the F2 generation. The cohabitation period was 6 days. When copulation was confirmed or the 6-day-cohabitation period was over, the F1 generation male mice were killed by exsanguination under ether narcosis, and samples of blood were collected. In addition to blood samples, liver, kidney, brain, testes, epididymis, seminal vesicles, and ventral prostate were collected immediately, weighed to the nearest milligram using a Shimadzu Electric balance.

\section{Analysis of sperm in F1 generation}

The cauda epididymal sperm, collected by chopping epididymis in $5.0 \mathrm{ml}$ Ham's F-12 medium, were incubated for $5 \mathrm{~min}$ at $32{ }^{\circ} \mathrm{C}$. The epididymal sperm were counted by the method as described previously using a Neubauer chamber (Belsey et al. 1980). Briefly, $5 \mu$ l epididymal sperm were diluted with $95 \mu l$ Ham's F-12 medium. The cover slips on the counting chambers of the improved Neubauer-type hemocytometer were secured. Approximately $10 \mu \mathrm{l}$ of the diluted sperm suspension was transferred to each counting chamber of the hemocytometer and was allowed to stand for $5 \mathrm{~min}$ in a humid chamber to prevent drying out. The cells that settled during this time were counted with the help of microscope (Olympus) at $200 \times$. The complete spermatozoa (head with tail) were counted.

Progressive sperm motility was evaluated by the method as describer earlier (Belsey et al. 1980). Briefly, fluid from cauda epididymides was obtained using a pipette tip and diluted to $2.0 \mathrm{ml} \mathrm{Ham}$ 's F-12 medium at $32{ }^{\circ} \mathrm{C}$. Approximately, $10 \mu \mathrm{l}$ of this solution was placed in Neubauer-type hemocytometer and counted for motile and non-motile sperm. First, non-motile sperm were counted followed by motile sperm. Sperm motility was expressed as a percentage of motile sperm of the total sperm counted.

The ratio of live and dead spermatozoa was determined using $1 \%$ trypan blue by the method of Talbot \& Chacon (1981). The function (HOS test) of the sperm was determined by exposing the sperm to hypo-osmotic medium and observed for coiled tails under a microscope, and the percentage of coiling was estimated by the method of Jeyendran et al. (1992).

\section{Assay of steroidogenic enzymes in the testis of F1 generation mice}

The testicular tissue was homogenized (5\%W/V) in ice-cold Tris- $\mathrm{HCl}$ buffer $(\mathrm{pH}$ 6.8). The microsomal fraction was separated and used as enzyme source. The activity levels of hydroxy-delta-5-steroid dehydrogenase, 3 beta- and steroid delta-isomerase cluster (HSD3B, EC 1.1.1.51) and hydroxysteroid (17-beta) dehydrogenase 1 (HSD17B, EC 1.1.1.61) were assayed by the method of Bergmeyer (1974). The reaction mixture in a volume of $2.0 \mathrm{ml}$ contained: $100 \mu \mathrm{mol}$ sodium pyrophosphate buffer ( $\mathrm{pH}$ 9.0), $0.5 \mu \mathrm{mol}$ cofactor NAD for HSD3B and NADPH for HSD17B, $0.08 \mu \mathrm{mol}$ substrate (DHEA for HSD3B and androstenedione for HSD17B) and $20 \mathrm{mg}$ equivalent of microsomal protein as enzyme source. The reactions were carried out in a quartz cuvette of $1.0 \mathrm{~cm}$ path at $23 \pm 1{ }^{\circ} \mathrm{C}$. The absorbance at $340 \mathrm{~nm}$ was measured at $20 \mathrm{~s}$ intervals for $5 \mathrm{~min}$ in a UV-VIS spectrophotometer (Hitachi model U-2001) against controls.

The enzyme assays were made under the conditions following zero order kinetics after preliminary standardization regarding linearity with respect to time of incubation and enzyme concentration. The protein content in the enzyme source was determined according to the method of Lowry et al. (1951) using BSA as standard. The enzyme activities were expressed in micromoles of NAD converted to $\mathrm{NADH} / \mathrm{mg}$ protein/min $(\mathrm{HSD} 3 \mathrm{~B})$ or micromoles of $\mathrm{NADPH}$ converted to $\mathrm{NADP} / \mathrm{mg}$ protein/min (HSD17B).

\section{Measurement of testosterone, $\mathrm{FSH}$ and $\mathrm{LH}$ in serum of F1 generation mice}

One blood sample was collected from the heart of each animal prior to necropsy. The serum was separated by centrifugation at $2000 \mathrm{~g}$ for $5 \mathrm{~min}$ after overnight storage at $4{ }^{\circ} \mathrm{C}$ and stored at $-20{ }^{\circ} \mathrm{C}$ until assayed. Radioimmunoassay of serum testosterone was performed by the method of Rao et al. (1990). The sensitivity of the assay was calculated as $0.002 \mathrm{ng}$ and intraassay variation was found to be $6.5 \%$. Serum FSH and $\mathrm{LH}$ were assayed according to the method of Lin et al. (1988). lodination of $\mathrm{rFSH}$ and $\mathrm{rLH}$ with ${ }^{125} \mathrm{I}$ was performed by the 
method of Greenwood et al. (1963) using chloramines-T as an oxidizing agent. The sensitivity of the assay was calculated as $0.008 \mathrm{ng}$ for $\mathrm{FSH}$ and $0.006 \mathrm{ng}$ for $\mathrm{LH}$. The intraassay variations were 5 and $6 \%$ for $\mathrm{FSH}$ and $\mathrm{LH}$ respectively. All of the samples were run at the same time to avoid interassay variation.

\section{Histology of testis of F1 generation mice}

Testis was isolated and the adhering tissue was removed and fixed in Bouin's fluid. After alcoholic gradient dehydration, tissue samples were fixed in paraffin, cut at $6 \mu \mathrm{m}$ thickness, stained with hematoxylin and counter-stained with eosin, and examined with a light microscope.

\section{Fertility test}

The objective of this fertility trial was to compare the capacity of animals to impregnate females. Control, experimental (F1 generation) mice exposed to progesterone during embryonic development with or without testosterone substitution were cohabited with untreated 60-day-old estrus females of proven fertility. Maximum duration of pairing was 6 days. Positive evidence of copulation was confirmed by the presence of vaginal plug and/or sperm in the vaginal smear taken each morning during cohabitation. The day on which evidence of copulation was identified was termed day zero of gestation. The number of pregnant mice in each group was recorded for determination of fertility index. Eight pregnant mice were laporatomized on sixth-day to determine the number of corpora lutea and the number of implantations. On the 18th day of gestation, eight mice were laporatomized and the total number of implantations was counted and fetuses were removed by uterine opening. The number of live and dead fetuses (embryos) was recorded. Mating index (number of sperm-positive females/number of pairings), fertility index (number of pregnant females/number of pairings), pre-implantation loss ((number of corpora lutea-number of implantations/number of corpora lutea $) \times 100)$ and post-implantation loss ((number of implantations - number of live fetuses/number of implantations) $\times 100$ ) were calculated. Fetal weight was also recorded.

\section{Statistical analysis}

The data were statistically analyzed by ANOVA followed by Dunnet's test for multiple comparisons using SPSS 16.0. The data were expressed as mean \pm s.D. and the values for $P<0.001$ were considered significant.

\section{Declaration of interest}

The authors declare that there is no conflict of interest that would prejudice the impartiality of this scientific work.

\section{Funding}

This work was supported by a research grant No: 32-502/2006 from University Grants Commission, New Delhi and grant No:
5/10/5/2005-RHN from Indian Council of Medical research, New Delhi to P S Reedy.

\section{Acknowledgements}

We thank Mr S Umasankar for maintaining the mice colony in the Department. The experiments were conducted following the rules and regulations of Institutional Animal Care and Ethics Committee and comply with the laws of the country. The authors gratefully acknowledge the assistance of Prof. K V S Sarma for statistical analysis of data and Dr T Pushpalatha for assistance with fetus collection and examination.

\section{References}

Aceitero J, Llanero M, Parrado R, Pena E \& Lopez-Beltran A 1998 Neonatal exposure of male rates to estradiol benzoate causes rat testis dilation and backflow impairment of spermatogenesis. Anatomical Records 252 17-33.

Adami HO, Bergstrom R, Mohner M, Zatonski W, Storm H, Ekbom A, Trettis T, Teppo L, Ziegler H \& Rahu M 1994 Testicular cancer in nine Northern European countries. International Journal of Cancer 59 33-38.

Aitken RJ, Skakkebaek NE \& Roman SD 2006 Male reproductive health and environment. Medical Journal of Australia 185 414-415.

Anway MD \& Skinner MK 2006 Endocrine disrupters trigger fertility problems in multiple generations. Endocrinology 147 18-24.

Arai V, Mori T, Suzuki Y \& Bern HA 1983 Long term effects of perinatal exposure of sex steroids and diethylstibestrol on the reproductive system of male mammals. International Reviews of Cytology 84 235-268.

Arslan M, Weinbauer GF, Schlatt S, Shahab M \& Nieschlag E 1993 FSH and testosterone alone or in combination initiate testicular growth and increase number of spermatogonia and sertoli cells is a juvenile nonhuman primate Macaca mulatta. Journal of Endocrinology 136 235-243.

Atanassova N, McKinnell C, Turner KJ, Walker M, Fisher JS, Morley M, Millar MR, Groome NP \& Sharpe RM 2000 Comparative effects of neonatal exposure of male rats to potent and weak environmental estrogens on spermatogenesis at puberty and the relationship to adult testis size and fertility: evidence for stimulatory effects of low estrogen levels. Endocrinology 141 3898-3907.

Barrett-Connor E \& Bhasin S 2004 Time for more research on testosterone. Journal of Clinical Endocrinology and Metabolism 89 501-502.

Bellido C, Pinilla L, Aguilar R, Gaytan F \& Aguilar E 1990 Possible role of changes in post-natal gonadotrophin concentrations on permanent impairment of the reproductive system in neonatally oestrogenized male rats. Journal of Reproduction and Fertility 90 369-374.

Belsey MA, Moghissi KS, Eliasson R, Paulsen CA, Callegos AJ \& Prasad MRN 1980 Laboratory Manual for the Examination of Human Semen and Semen-Cervical Mucus Interaction, Singapore: Press Concern.

Bergmeyer HU 1974 In Methods of Enzymatic Analysis, pp 447-489. Ed. HU Bergmeyer. New York: Academic Press.

Bhasin S \& Bremner WJ 1997 Clinical review 85: emerging issues in androgen replacement therapy. Journal of Clinical Endocrinology and Metabolism 82 3-8.

Brown-Grant K, Fink G, Greig F \& Murray MA 1975 Altered sexual development in male rats after oestrogen administration during the neonatal period. Journal of Reproduction and Fertility $4425-42$.

Carlsen E, Giwercman A, Keiding N \& Skakkebaek NE 1992 Evidence for decreasing quality of semen during the last 50 years. BMJ 305 609-613.

Cooke GM, Price CA \& Oko RJ 1998 Effects of in utero and lactational exposure to 2378 -tetrachloro dibenzo- $p$-dioxin TCDD on serum androgens and steroidogenic enzyme activities in the male rat reproductive tract. Journal of Steroid Biochemistry and Molecular Biology 674 347-354.

Fielden MR, Halgren GR, Fong JC, Staub C, Johnson L, Chou K \& Zacharewski RT 2002 Gestational and lactational exposure of male mice to diethylstilbestrol causes long-term effects on the testis sperm fertilizing ability in vitro and testicular gene expression. Endocrinology 143 3044-3059. 
Fisher CR, Graves KH, Parlow AF \& Simpson ER 1998 Characterization of mice deficient in aromatase (ArKo) because of targeted disruption of the cyp19 gene. PNAS 95 6965-6970.

Forman D \& Moller H 1994 Testicular cancer. Cancer Survey 20 323-341. Gill WB, Schumacher GF, Bibbo M, Straus FAD \& Schoenberg HW 1979 Association of diethylstilbestrol exposure in utero with cryptorchidism testicular hypoplasia and semen abnormalities. Journal of Urology $\mathbf{1 2 2}$ 36-39.

Goyal HA, Robateau A, Braden TD, Williams CS, Srivastava KK \& Ali K 2003 Neonatal estrogen exposure of male rats alters reproductive functions at adulthood. Biology of Reproduction 68 2081-2091.

Goyal HO, Braden TD, Williams CS, Dalvi P, Mansour MM, Mansour M, Williams JW, Bartol FF, Wiley AA, Birch L et al. 2004 Abnormal morphology of the penis in male rats exposed neonatally to diethylstilbestrol is associated with altered profile of estrogen receptor- $\alpha$ protein but not of androgen receptor protein: a developmental and immunocytochemical study. Biology of Reproduction 70 1504-1517.

Greenwood FC, Hunter WM \& Clover JS 1963 The preparation of ${ }^{131}$ I labeled human growth hormone of high specific radio activity. Biochemistry Journal 89 114-123.

Hess RA, Gist DH, Bunick D, Lubahn DB, Farrell A, Bahr J, Cooke PS \& Greene GL 1997 Estrogen receptors $\alpha$ and $\beta$ expression in the excurrent ducts of the adult male rat reproductive tract. Journal of Andrology 18 602-611.

Hines M 1992 The wild life-human connection. In Modern Environmental Toxicology, pp 261-281. Eds T Colborn \& C Clement. Princeton, NJ: Princeton Scientific publishing Co.

Jensen TK, Toppari J, Keiding N \& Skakkebaek NE 1995 Do environmental estrogens contribute to the decline in male reproductive health? Clinical Chemistry 41 1896-1901.

Jeyendran RS, Van Der Ven HH \& Zaneveld LJD 1992 The hypoosmotic swelling test: an update. Archives of Andrology 29105.

Jones LA 1980 Long-term effects of neonatal administration of estrogen and progesterone alone or in combination on male BALB/C and BALB/CF $3 \mathrm{H}$ mice 40927. Proceedings of the Society for Experimental Biology and Medicine 165 17-25.

Kaneto M, Kanomori S, Hishikawa A \& Kishi K 1999 Epididymal sperm motion as a parameter of male reproductive toxicity: sperm motion, fertility, and histopathology in ethinylestradiol-treated rats. Reproductive Toxicology 13 279-289.

Khan SA, Ball RB \& Hendry WJ III 1998 Effects of neonatal administration of diethylstilbestrol in male hamsters: disruption of reproductive function in adults after apparently normal pubertal development. Biology of Reproduction 58 137-142.

Korach KS, Couse JF, Curtis SW, Washburn TF, Lindzey J, Lubahn DB, Eddy EM, Snedeker SM, Schomberg DW \& Smith EP 1996 Estrogen receptor gene disruption: molecular characterization and experimental and clinical phenotypes. Recent Progress in Hormone Research $\mathbf{5 1}$ 159-186.

Lee PC 1998 Disruption of male reproductive tract development by administration of the xenoestrogen nonylphenol to male newborn rats. Endocrine 9 105-111.

Lin KC, Kawamura N, Okamura H \& Mori T 1988 Inhibition of ovulation steroidogenesis and collagenolytic activity in rabbits by sulphide induced hyperprolactinemia. Journal of Reproduction and Fertility $\mathbf{8 3}$ 611-618.

Lowry H, Rosebrough NI, Far AL \& Ranall RJ 1951 Protein measurement with folinphenol reagent. Journal of Biological Chemistry 193 265-275.

Luconi M, Forti F \& Baldi E 2002 Genomic and nongenomic effects of estrogens: molecular mechanisms of action and clinical implications for male reproduction. Journal of Steroid Biochemistry and Molecular Biology 80 369-381.

Mann T 1974 Secretory function of the prostate, seminal vesicle and other male accessory organs of reproduction. Journal of Reproduction and Fertility 37 179-188.

Marselos M \& Tomatis L 1992 Diethylstilbestrol. II. Pharmacology toxicology and carcinogenicity in experimental animals. European Journal of Cancer 29 149-155.

McGinley J, Sanchez RS, Spencer JR, Yee B \& Yaughan ED 1992 Comparision of the effects of the $5 \alpha$ - reductase inhibitor finasteroid and the antiandrogen flutamide on prostate and genital differentiation: dose-response studies. Endocrinology 131 1149-1156.
McKinnell C, Atanassova N, Williams K, Fisher JS, Walker M, Turner KJ, Saunders TK \& Sharpe RM 2001 Suppression of androgen action and the induction of gross abnormalities of the reproductive tract in male rats treated neonatally with diethylstilbestrol. Journal of Andrology 22 323-338.

McLachlan JA, New bold RR \& Bullock B 1975 Reproductive tract lesions in male mice exposed prenatally to diethylstilbestrol. Science $\mathbf{1 9 0}$ 991-992.

McLachlan RI, Wreford NG, O'Donnell L, Dekretser DM \& Robertson DM 1996 The endocrine regulation of spermatogeneisis independent role for testosterone and FSH. Journal of Endocrinology 148 1-9.

Meistrich ML 1989 Caliculation of the incidence of infertility in human populations from sperm measures using the two-distribution model. Progress in Clinical and Biological Research 302 275-285.

Nelson EM \& Bunge RG 1974 Semen analysis: evidence for changing parameters of male fertility potential. Fertility and Sterility 25 503-507.

Newbold RR \& McLachlan JA 1985 Diethylstibestrol associated defects in murine genital tract development. In Estrogens in the Environment II, pp 288-318. Ed. JA McLachlan. New York: Elsevier.

O'Donnell L, Robertson KM, Jones ME \& Simpson ER 2001 Estrogen and spermatogenesis. Endocrinology Reviews 22 289-318.

Orgebin-Crist MC, Eller BC \& Danzo BJ 1983 The effects of estradiol tamoxifen and testosterone on the weights and histology of the epididymis and accessory sex organs of sexually immature rabbits. Endocrinology 113 1703-1715.

Pakarainen T, Zhang FP, Makelia S, Poutanen M \& Huhtaniemi I 2005 Testosterone replacement therapy induce spermatogenesis and partially restore fertility in luteinizing hormone receptor knock out mice. Endocrinology 146 596-606.

Paulozzi L 1999 International trends in rates of hypospadias and cryptorchidism. Environment Health Perspectives 107 297-302.

Pushpalatha T, Reddy PR \& Reddy PS 2003 Effect of prenatal exposure to hydroxyprogesterone on steroidogenic enzymes in male rats. Naturwissenschaften 90 40-43.

Pushpalatha T, Reddy PR \& Reddy PS 2004 Impairment of male reproduction in prenatally hydroxyprogesterone caproate exposed rats. Naturwissenschaften 91 242-244.

Pushpalatha T, Reddy PR \& Reddy PS 2005 Gestational exposure to hydroxyprogesterone caproate suppresses reproductive potential in male rats. Naturwissenschaften 92 385-388.

Putz O, Scwartz CB, LeBlanc GA, Cooper RI \& Prins GS 2001 Neonatal low- and high-dose exposure to estradiol benzoate in the male rat. II. Effect on male puberty and the reproductive tract. Biology of Reproduction 65 1506-1517.

Rao MV \& Chinoy NJ 1983 Effect of estradiol benzoate on reproductive organs and fertility in the male rat. European Journal of Obstetrics, Gynecology, and Reproductive Biology 15 189-198.

Rao AJ, Charaborti R, Kotagi SG \& Ravindranath N 1990 Effect of constant infusion of gonadotropins releasing hormone $\mathrm{GnRH}$ against buserelin and antagonist CDB 2085 A using osmotic mini pumps on testicular function in adult male bonnet monkey Macaca radiate. Andrologia 22 567-573.

Rivas A, McKinnell C, Fisher JS, Atanassova N, Williams K \& Sharpe RM 2003 Neonatal coadministration of testosterone with diethylstilbestrol prevents diethylstilbestrol induction of most reproductive tract abnormalities in male rats. Journal of Andrology 24 557-567.

Robbins A 1996 Androgens and male sexual behaviour from mice to men. Trends in Endocrinology and Metabolism 7 345-350.

Sharpe RM \& Skakkebaek NE 1993 Are estrogens involved in falling sperm counts and disorders of the male reproductive tract? Lancet $\mathbf{3 4 1}$ 1392-1395.

Sharpe RM, Atanassova N, McKinnell C, Parte P, Turner KJ, Fisher JS, Kerr JB, Groome NP, Macpherson S, Millar MR et al. 1998 Abnormalities in functional development of the Sertoli cells in rats treated neonatally with diethylstilbestrol: a possible role for estrogens in Sertoli cell development. Biology of Reproduction 59 1084-1094.

Takasugi N \& Bern HA 1988 Introduction: abnormal genital tract development in mammals following early exposure to sex hormones. In Toxicity of Hormones in Perinatal Life, pp 1-7. Eds T Moori \& H Nagasawa. Boca Raton, FL: CRS Press. 
Takihara H, Cosentino MJ, Sakatoku J \& Cockett AT 1987 Significance of testicular size measurement in andrology. II. Correlation of testicular size with testicular function. Journal of Urology 137 416-419.

Talbot P \& Chacon RS 1981 A triple stain technique for evaluating normal acrosome reaction of human sperm. Journal of Experimental Zoology 215 201-208.

Thayer KA, Ruhlen RL, Howdeshell KL, Buchanan DL, Cooke PS, Preziosi O, Welshons WV, Haseman J \& vom Saal FS 2001 Altered prostate growth and daily sperm production in male mice exposed prenatally to subclinical doses of $17\{\alpha\}$-ethinyl oestradiol. Human Reproduction 16 988-996.

Van Thiel DH, Sherins RJ, Myers GH Jr \& de Vita VT Jr 1972 Evidence for a specific seminiferous tubular factor affecting follicle-stimulating hormone secretion in man. Journal of Clinical Investigation $\mathbf{5 1}$ 1009-1019.

Toppari J, Larsen JC, Christiansen P, Giwercman A, Grandjean P, Guillette LJ Jr, Jegou B, Jensen TK, Jouannet P, Keiding N et al. 1996 Male reproductive health and environmental xenoestrogens. Environmental Health Perspectives 104 741-803.

Udagawa K, Ogawa T, Watanabe T, Tamura Y, Kita K \& Yoshinobu K 2006 Testosterone administration promotes regeneration of chemically impaired spermatogenesis in rats. International Journal of Urology 13 1103-1108
Vandenbergh JG 2004 Animal models and studies of in utero endocrine disruptor effects. ILAR Journal 5 438-440.

Vornberger W, Prins G, Musto NA \& Suarez-Quian CA 1994 Androgen receptor distribution in rat testis: new implications for androgen regulation of spermatogenesis. Endocrinology 134 2307-2316.

Vos JG, Dybing E, Greim HA, Ladefoged O, Lambrc C, Tarazona JV, Brandt I \& Vethaak AP 2000 Health effects of endocrine - disrupting chemicals on wild life with special reference to the European situation. Critical Reviews of Toxicology 30 71-133.

Weinbauer GF \& Nieschlag E 1990 The role of testosterone is spermatogenesis. In Testosterone Action Deficiency Substitution, pp 23-50. Eds E Nieschlag \& HM Behre. Berlin Hcidelberg: Verlag-Springer.

Wilson JD 1990 Androgens. In Goodman and Gilman's the Pharmacological Basis of Therapeutics, 8th edn, pp 1413-1430. New York: Pergamon Press.

Received 7 June 2008

First decision 15 July 2008

Revised manuscript received 17 October 2008

Accepted 28 November 2008 